\title{
TINGKAT PENGETAHUAN KESEHATAN GIGI ANAK SEKOLAH DASAR NEGERI KAUMAN 2 MALANG
}

\author{
Rara Warih Gayatri \\ Desi Ariwinanti \\ Fakultas Ilmu Keolahragaan Universitas Negeri Malang \\ Email: rara.warh.fik@gmail.com
}

\begin{abstract}
The problem of dental caries remains a problem globally. More than $90 \%$ of the world population have experienced dental caries. According to Gayatri (2015), the dental caries status among school-aged children in SDN Kauman 2 Malang shown the score of DMF-T index 5.75 and was considered high. The purpose of this study was to determine the level of dental health knowledge among school-aged children in SDN Kauman 2 Malang. This was a cross-sectional quantitative descriptive research. The sampling method used stratified random sampling and the measured variable was the level of dental health knowledge. Data collection technique used a questionnaire containing a set of questions to children aged 6-12 years. Data processing included editing, coding, scoring, data entry and cleaning. The data was analysed using univariate statistical method. The result of this study shown 82.9\% $(n=63)$ 5-6 grade students of SDN Kauman 2 had a high level of dental health knowledge and $17.1 \%(n=13)$ had a low level of dental health knowledge. In this regard, a good level of dental health knowledge is expected to support the establishment of good dental health behaviour. The recommendation from this study was the need for a further research on a relation between knowledge, attitude and behaviour of dental health in students of SDN Kauman 2 Malang.
\end{abstract}

Kata kunci : Knowledge, dental health, school-aged children

\begin{abstract}
Abstrak : Karies gigi masih menjadi permasalahan dunia. Lebih dari 90\% penduduk dunia mengalami karies gigi. Menurut Gayatri (2015) gambaran status karies gigi anak usia sekolah di SDN Kauman 2 Kota Malang menunjukkan nilai indeks DMF-T 5,75 yang berarti prevalensi karies gigi dianggap tinggi. Tujuan penelitian ini untuk mengetahui tingkat pengetahuan kesehatan gigi pada anak SDN Kauman 2 Malang. Penelitian ini menggunakan metode deskriptif kuantitatif dengan desain potong lintang (cross-sectional). Metode sampling yang digunakan merupakan metode stratified random sampling dengan variabel yang diukur adalah tingkat pengetahuan kesehatan gigi. Teknik pengumpulan data menggunakan kuesioner dengan memberikan seperangkat pertanyaan kepada anak usia 6-12 tahun. Pengolahan data yang dilakukan meliputi proses editing, coding, scoring, data entry dan cleaning. Analisa data dilakukan dengan analisis statistik univariat. Hasil dari penelitian ini adalah sebanyak 82,9\% (n=63) siswa kelas 5-6 SDN Kauman 2 memiliki tingkat pengetahuan kesehatan gigi tinggi dan sebanyak $17,1 \%(n=13)$ memilki tingkat pengetahuan kesehatan gigi rendah. Dalam hal ini, tingkat pengetahuan yang baik mengenai kesehatan gigi diharapkan dapat mendukung terbentuknya perilaku kesehatan gigi yang baik pula. Saran dari penelitian ini, perlu adanya penelitian lanjutan mengenai hubungan antara pengetahuan, sikap dan perilaku tentang kesehatan gigi pada anak SDN Kauman 2 Malang.
\end{abstract}

Kata kunci: pengetahuan, kesehatan gigi, anak sekolah dasar

Angka kejadian dari gigi berlubang (karies gigi) masih sangat tinggi terutama pada anak-anak. Kerusakan gigi yang terjadi pada masa anak-anak tentunya mempengaruhi keadaan gigi geligi saat dewasa. Hampir $90 \%$ anak - anak usia sekolah di seluruh dunia menderita karies gigi (Bagramian dkk, 2009). Sementara itu, menurut Centers of Control Disease Prevention (CDC, 2013), meskipun karies gigi merupakan penyakit yang harus bisa dicegah akan tetapi tetap menjadi penyakit kronis yang sering terjadi pada anak usia 6-11 tahun (25\%) serta remaja usia 12-19 tahun (59\%). Hal ini juga menjadi permasalahan di Indonesia yang terlihat dalam dalam Survei Kesehatan Rumah tangga (SKRT) tahun 2001 oleh Rahardjo (2007) dimana terdapat 76,2\% anak Indonesia pada kelompok usia 12 tahun (kira-kira 8 dari 10 anak) mengalami gigi berlubang. Temuan ini juga didukung oleh data Kementrian Kesehatan Republik Indonesia (Kemenkes RI) tahun 2009 (dalam Wala, dkk., 2014) yang menunjukan sebanyak 89\% anak Indonesia di bawah 12 tahun menderita karies gigi.

Karies gigi merupakan penyakit yang disebabkan oleh banyak faktor. Adapun faktor utama penyebab karies yaitu host (gigi dan saliva), mikroorganisme (plak), substrat (karbohidrat) dan ditambah faktor waktu (Sondang dan Hamada, 2008). Selain itu, faktor predisposisi lain yang turut berkontribusi terhadap keparahan karies 
antara lain pengalaman karies, sosial ekonomi, usia, jenis kelamin, geografis, dan perilaku terhadap kesehatan gigi (Sondang dan Hamada, 2008).

Pengetahuan seseorang tentang perilaku memelihara kesehatan gigi dan mulut seringkali terdapat ketidakselarasan. Berdasarkan Riset Kesehatan Dasar (2007) 91,1\% masyarakat Indonesia menggosok gigi tiap hari namun hanya $7,3 \%$ dari data tersebut yang melakukan gosok gigi dengan benar. Kenyataan yang lain dapat ditunjukkan pada perilaku masyarakat yang mengunjungi fasilitas pelayanan kesehatan gigi apabila sudah dalam keadaan sakit gigi yang parah (Suwelo, 1997). Hal ini dapat diartikan bahwa, kesadaran masyarakat untuk berobat sedini mungkin masih rendah sehingga dalam perilaku mengunjungi fasilitas pelayanan kesehatan gigi juga kurang (Suwelo, 1997). Di Indonesia, kurang dari $7 \%$ orang dewasa dan $4 \%$ anak-anak yang memiliki kesadaran untuk mengunjungi fasilitas pelayanan kesehatan gigi (Lukihardianti, 2011).

Gambaran kondisi diatas didukung oleh beberapa studi yang menunjukkan hubungan signifikan tentang pengetahuan dan kesehatan gigi dan mulut. Menurut Ariska (2014) dalam penelitiannya menyebutkan bahwa pengetahuan sebagai salah satu faktor yang mempengaruhi personal hyigiene seseorang. Fankari (2004) juga menegaskan bahwa penyebab timbulnya masalah gigi dan mulut pada masyarakat salah satunya adalah faktor perilaku atau sikap mengabaikan kebersihan gigi dan mulut. Hal ini dilandasi oleh kurangnya pengetahuan akan pentingnya pemeliharaan gigi dan mulut. Kawuryan (2008) menjelaskan bahwa dengan adanya pengetahuan tentang kesehatan gigi dan mulut secara tidak langsung akan menjaga kesehatan gigi dan mulut sehingga pada akhirnya dapat mencegah karies gigi. Hal ini berarti berarti pengetahuan tentang kesehatan gigi dan mulut juga berdampak pada kejadian karies gigi.

Sementara itu, kondisi anak-anak usia sekolah dasar dengan karies gigi di Kota Malang juga bervariasi. Berdasarkan hasil penelitian sebelumnya oleh Gayatri (2015) diperoleh prevalensi karies gigi anak-anak sekolah dasar di

\section{Hasil:}

Responden penelitian ini berjumlah 76 siswa dari 81 siswa. 5 responden tidak termasuk sebagai
SDN Kauman 2 Malang dan SDN Percobaan 2 Malang menunjukkan indeks DMF-T tinggi yaitu sebesar 5,75. Menurut WHO (2003), indeks DMF$\mathrm{T}$ tinggi adalah pada rentang 4,5-6,5. Gambaran karakteristik responden penelitian tersebut adalah anak sekolah dasar usia 6-12 tahun sejumlah 284 responden, 138 siswa SDN Kauman 2 Malang dan 146 siswa SDN Percobaan 2 Malang. Terkait temuan pada penelitian ini, peneliti bermaksud melakukan penelitian lanjutan untuk mengetahui faktor predisposisi kejadian karies gigi pada anak sekolah dasar di SDN Kauman 2 Malang. Dalam hal ini, terutama diliat dari aspek pengetahuan anak-anak tersebut tentang kesehatan gigi dan mulut

\section{Metode}

Desain penelitian ini adalah penelitian deskriptif kuantitatif dengan pendekatan crosssectional yang dilaksanakan pada bulan MeiOktober 2015 dengan lokasi penelitian adalah Sekolah Dasar Negeri Kauman 2 Malang. Teknik sampling yang digunakan adalah total sampling sehingga subyek penelitian adalah keseluruhan siswa kelas 5 dan 6 SDN Kauman 2 Malang sejumlah 81 siswa. Subyek penelitian yang dimaksud memenuhi kriteria inklusi yaitu Anak usia sekolah 10-12 tahun, memahami bahasa Indonesia dan dapat membaca menulis dan bersedia menjadi responden. Teknik pengumpulan data penelitian ini adalah wawancara dengan menggunakan kuesioner. Pengukuran variabel pengetahuan menggunakan skala Guttman dimana pilihan jawaban benar dan salah. Anak diminta untuk memilih manakah jawaban yang sesuai dengan pengetahuan yang dimiliki. Nilai minimal $=0$ dan nilai maksimal $=15$. Pengolahan data yang dilakukan meliputi proses editing, coding, scoring, data entry dan cleaning. Teknik analisis statistik yang dipergunakan pada penelitian ini adalah analisis univariat dimana data yang telah terkumpul dihitung untuk melihat persentase jumlah data yang ada. Kategorisasi tingkat pengetahuan yaitu siswa memiliki tingkat pengetahuan tinggi apabila nilai $\mathrm{x}>11$ mean dan siswa memiliki tingkat pengetahuan rendah apabila nilai $\mathrm{x} \leq 11($ Mean $=11)$.

\section{Usia}


subyek penelitian disebabkan karena tidak mengisi termasuk dalam kriteria eksklusi dari penelitian. kuesioner dengan lengkap. Sehingga dalam hal ini

Tabel 1. Karakteristik Responden Berdasarkan Usia di SDN Kauman 2 Malang

\begin{tabular}{ccc}
\hline Usia & Frekuensi $(\mathbf{n})$ & Persentase $(\boldsymbol{\%})$ \\
\hline 10 tahun & 17 & 22,4 \\
11 tahun & 40 & 52,6 \\
12 tahun & 19 & 25,0 \\
Total & 76 & 100 \\
\hline
\end{tabular}

Berdasarkan tabel di atas diketahui bahwa dari 76 orang yang menjadi sampel pada penelitian ini, sebanyak 40 orang berusia 11 tahun, 19 orang berusia 12 tahun dan 17 orang berusia 10 tahun.

\begin{tabular}{ccccccc}
\hline Variabel & Mean & Median & Modus & Standart deviasi & Min-Maks & CI (95\%) \\
\hline Usia & 11,03 & 11 & 11 & 0,69 & $10-12$ & $10,87-11,18$ \\
\hline
\end{tabular}

Berdasarkan tabel di atas di ketahui bahwa ratarata usia responden yang menjadi sampel pada penelitian ini sebesar 11,03 dengan median usia adalah 11 tahun, modus 11 tahun dan standart deviasi 0,69 . Usia responden berkisar antara 10 hingga 12 tahun.

\section{Jenis Kelamin}

Tabel 2. Karakteristik Responden Berdasarkan Jenis Kelamin di SDN Kauman 2 Malang

\begin{tabular}{ccc}
\hline Jenis Kelamin & Frekuensi (n) & Persentase $(\boldsymbol{\%})$ \\
\hline Laki-laki & 41 & 53,9 \\
Perempuan & 35 & 46,1 \\
Total & 76 & 100 \\
\hline
\end{tabular}

Berdasarkan tabel di atas diketahui bahwa dari 76 orang yang menjadi sampel pada penelitian ini, sebanyak 41 orang adalah laki-laki dan 35 orang lainnya adalah perempuan.

\section{Pengetahuan kesehatan gigi}

Tabel 3. Distribusi Frekuensi Berdasarkan Pengetahuan Kesehatan Gigi di SDN Kauman 2 Malang

\begin{tabular}{ccc}
\hline Pengetahuan kesehatan gigi & Frekuensi (n) & Persentase $(\boldsymbol{\%})$ \\
\hline Rendah & 13 & 17,1 \\
Tinggi & 63 & 82,9 \\
Total & 76 & 100 \\
\hline
\end{tabular}

Berdasarkan tabel di atas di ketahui bahwa dari 76 orang yang menjadi sampel pada penelitian ini, sebanyak 63 orang memiliki pengetahuan kesehatan gigi yang tinggi dan13 orang lainnya memiliki pengetahuan kesehatan gigi yang rendah 


\begin{tabular}{cccccccc}
\hline Mean & Median & Modus & Skewness & $\begin{array}{c}\text { Std. Eror of } \\
\text { skewness }\end{array}$ & $\begin{array}{c}\text { Nilai min- } \\
\text { maks }\end{array}$ & $>$ mean & $\leq$ mean \\
\hline 12,55 & 13 & 13 & $-0,905$ & 0,276 & $8-15$ & 63 & 13 \\
\hline
\end{tabular}

Berdasarkan tabel di atas di ketahui bahwa ratarata pengetahuan kesehatan gigi responden sebesar 12,55 dengan median adalah 13 dan modus 13 . Nilai skewness pengetahuan kesehatan gigi sebesar -0,905 dengan standart error skewness

\section{Pembahasan}

Hasil dari penelitian ini selanjutnya akan dikaji dengan teori yang berlaku. Karakteristik responden pada penelitian ini adalah siswa SDN Kauman 2 Malang berusia $10-12$ tahun sejumlah 76 orang. Responden terbanyak pada usia 11 tahun dengan jumlah 40 siswa. Hal ini disebabkan sebaran siswa menurut umur pada kelas 5 dan 6 rata-rata terbanyak pada usia 11 tahun. Menurut CDC (2014) karies gigi merupakan penyakit kronis dengan prevalensi yang cukup tinggi pada anak usia sekolah dasar (6-11 tahun). Sementara itu, menurut WHO (2000), target pelayanan kesehatan gigi 2010 antara lain anak umur 5 tahun $90 \%$ bebas karies dan anak umur 12 tahun mempunyai tingkat keparahan kerusakan gigi (Indeks DMF-T) sebesar 1.

Sementara itu, pada penelitian ini jumlah responden dengan jenis kelamin laki-laki 41 siswa) lebih banyak dibanding dengan jenis kelamin perempuan (35 siswa). Hal ini disebabkan karena distribusi frekuensi siswa SDN Kauman 2 Malang lebih banyak siswa laki-laki (145 siswa) dibanding siswa perempuan (139 siswa) (Gayatri, 2015). Meskipun dalam penelitian ini tidak dihubungkan dengan prevalensi karies gigi pada responden, penelitian sebelumnya oleh Gayatri (2015) pada siswa SDN Kauman 2 Malang menunjukkan bahwa indeks DMF-T pada laki-laki lebih tinggi dibandingkan pada perempuan.

Berdasarkan hasil analisis data, diketahui

\section{Kesimpulan}

Dalam penelitian dapat ditarik beberapa kesimpulan terkait tingkat pengetahuan kesehatan gigi anak usia sekolah dasar negeri Kauman 2 malang. Berdasarkan hasil analisis data, diketahui bahwa sebanyak 82,9 \% (n=63) siswa kelas 5-6 sebesar 0,276. Nilai pengetahuan kesehatan gigi berkisar antara 8 hingga 15 . Responden yang memiliki nilai pengetahuan kesehatan gigi di atas rata-rata sebanyak 63 orang sedangkan yang dibawah rata-rata sebanyak 13 orang.

bahwa sebanyak 82,9 \% (n=63) siswa kelas 5-6 SDN Kauman 2 memiliki tingkat pengetahuan kesehatan gigi tinggi dan sebanyak $17,1 \% \quad(n=13)$ memilki tingkat pengetahuan kesehatan gigi rendah. Pengetahuan kesehatan gigi dalam hal ini dibagi berdasarkan beberapa sub variabel yaitu pengetahuan tentang penyakit gigi, penyebab penyakit gigi, akibat penyakit gigi dan perilaku pemeliharaan kesehatan gigi. Hasil penelitian ini tidak jauh berbeda dengan hasil penelitian terdahulu oleh Dewanti (2012), dimana diketahui bahwa 54,2 \% siswa SDN Pondok Cina Depok memiliki tingkat pengetahuan tinggi. Penelitian oleh Kurniastuti (2015) juga memperoleh hasil yang tidak jauh berbeda yaitu kurang lebih $70 \%$ siswa SDN Grabag Kecamatan Grabag Kabupaten Purworejo memiliki tingkat pengetahuan kesehatan gigi sedang sampai tinggi.

Siswa SDN Kauman 2 Malang kelas 5 dan 6 mengetahui tentang penyakit gigi dengan baik. Pengetahuan merupakan domain yang sangat penting untuk membentuk perilaku seseorang. Pengetahuan siswa sangat penting dalam mendasari terbentuknya perilaku mendukung kebersihan gigi dan mulutnya (Sariningrum dkk., 2009 dan Ignatia dkk, 2013). Pengetahuan kesehatan gigi dan mulut sangat penting untuk terbentuknya tindakan menjaga kebersihan gigi dan mulut (Lintang dkk, 2015). Menjaga kebersihan gigi dan mulut pada usia sekolah merupakan salah satu cara dalam meningkatkan kesehatan sejak dini (Herijulianti dkk, 2001).

SDN Kauman 2 memiliki tingkat pengetahuan kesehatan gigi tinggi dan sebanyak $17,1 \%(n=13)$ memiliki tingkat pengetahuan kesehatan gigi rendah. 


\section{Saran}

Berdasarkan kesimpulan diatas, dapat diajukan beberapa saran antara lain, perlu adanya penelitian lanjutan mengenai hubungan antara pengetahuan, sikap dan perilaku tentang kesehatan gigi pada anak SDN Kauman 2 Malang. Selain itu, perlu adanya usaha peningkatan pengetahuan kesehatan gigi yang inovatif dan kreatif ditujukan kepada sasaran anak usia sekolah.

\section{Daftar Pustaka}

Ariska, Maulida. 2014. Faktor-faktor personal hygiene yang berhubungan dengan kebersihan gigi dan mulut masyarakat Desa Jumphoih Adan Kecamatan Mutiara Kabupaten Pidie, (Online), http://etd.unsyiah.ac.id/index.php?p=show _detail\&id=7958. Diakses tanggal: 30 Maret 2016

Bagramian, R., Godoy, F., Volpe, A. 2009 ' The global increase in dental caries. A pending public health crisis', (Online), http://amjdent.com/Archive/2009/Bagrami an\%20-\%20February\%202009.pdf. Diakses tanggal: 30 Maret 2016.

Centers of Control Diseases Prevention. 2013. Preventing dental caries with community programs,(online),

http://www.cdc.gov/oralhealth/publication s/factsheets/dental_caries.htm. Diakses tanggal 30 Maret 2016.

Fankari. 2004. Pengaruh penyuluhan dengan metode Stimulasi dan demonstrasi terhadap Perubahan perilaku menjaga kesehatan gigi dan mulut anak sekolah dasar. Karya tulis ilmiah DIV.

Gayatri, Rara Warih. 2015. Gambaran Karies gigi anak usia sekolah dasar di Kota Malang. Journal Preventia Vol 1 No 1 Juni 2015 hal 4250.. Malang: UM Press

Kawuryan, U. 2008. Hubungan pengethauan tentang kebersihan gigi dan mulut dengan kejadian karies anak SDN Kleco II kelas V dan VI Laweyan Surakarta. Skripsi. Surakarta: Universitas Muhammadiyah Surakarta (tidak dipublikasikan)
Lukihardianti, A. 2011. Sekitar $85 \%$ anak usia sekolah di Indonesia menderita karies gigi, (Online), http://www.republika.co.id/berita/gayahidup/info-sehat/11/09/12/lrevhf-sekitar85-persen-anak-usia-sekolah-menderitakaries-gigi. Diakses tanggal : 29 Maret 2016

Riset Kesehatan Dasar (Riskesdas). 2007. Laporan Nasional 2007. Jakarta: Balitbangkes Depkes

Sondang, P dan Hamada, T. 2008. Menuju gigi dan Mulut Sehat: Pencegahan dan Pemeliharaan, (Online), http://usupress.usu.ac.id/files/Menuju\%20 Gigi\%20dan\%20Mulut\%20Sehat\%20_Pen cegahan $\% 20$ dan $\% 20$ Pemeliharaan_Norm al_awal.pdf. Diakses tanggal 29 Maret 2016.

Suwelo, I.S.1997. Peranan pelayanan kesehatan gigi anak dalam menunjang kualitas sumber daya manusia Indonesia di masa mendatang. Disertasi. Jakarta: tidak dipublikasi

Wala, H., Wicaksono, D. dan Tambunan, E. 2014. Gambaran status karies gigi anak usia 1112 tahun pada keluarga pemegang Jamkesmas di Kelurahan Tumatangtang I Kecamatan Tomohon Selatan, (online), http://download.portalgaruda.org/article.ph $\mathrm{p}$ ? article $=146228 \& \mathrm{val}=1000 \&$ title $=\mathrm{GAM}$

BARAN\%20STATUS\%20KARIES\%20G IGI\%20ANAK\%20USIA\%2011$12 \% 20$ TAHUN\%20PADA\%20KELUAR GA\%20PEMEGANG\%20JAMKESMAS $\%$ 20DI\%20KELURAHAN\%20TUMATA NGTANG\%20I\%20KECAMATAN\%20T OMOHON\%20SELATAN. Diakses tanggal: 30 Maret 2016.

World Health. Organization (WHO). 2003. Oral Health Information System, (Online), http://www.who.int/oral_health/action/info rmation/surveillance/en/. Diakses tanggal: 30 Maret 2016. 